\title{
The Fall
}

\section{'MAGGIE' SMITH}

From Shaw the Villager, pp. 49-50. Shaw's final illness was precipitated by a fall which occurred in his garden at Ayot St Lawrence on Sunday 10 September 1950, while he was pruning a tree. He suffered a fractured thigh, and was admitted to the Luton and Dunstable General Hospital. The doctor who attended Shaw in his last illness was Thomas C. Probyn, of the nearby village of Kimpton. At the time of the fall Mrs Smith had returned to Shaw's service to replace Mrs Laden who was on holiday.

It was a terrible moment for me when I heard him whistle on my first day back with him. He carried a whistle with him always, to blow if he fell over or anything like that. He was a bit shaky on his feet sometimes. He was ninety-four, remember. I ran out into the garden and found him on the ground. I had him sitting on my knees for fifteen minutes. 'Put me down and go and fetch someone,' he said, but I wouldn't put him on the wet grass and blew and blew at the whistle till my husband, who happened to be near, came and helped Mr Shaw into the house. Then the doctor arrived a little later.

Mr Shaw had had enough - he didn't want to recover. He was a very determined man and no one could make him do anything he didn't want to.

\section{Last Days: I}

\section{F. G. PRINCE-WHITE}

From F. G. Prince-White, "“I Would Like to Go into My Garden," said Shaw', Daily Mail, 13 October 1950. Shaw returned home twenty-four days after his accident, on 4 October. In hospital he had successful operations on his thigh and kidney, but refused a second kidney operation which had been prescribed. On his return home, Shaw was nursed by Sisters Gwendoline Howell and Florence Horan. 